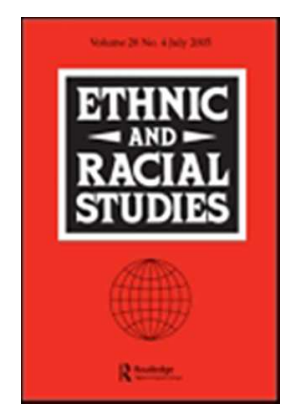

\title{
Nigerian London: remapping space and ethnicity in superdiverse cities
}

\begin{tabular}{|r|l|}
\hline Journal: & Ethnic and Racial Studies \\
\hline Manuscript ID: & RERS-2011-0110.R3 \\
\hline Manuscript Type: & Original Manuscript \\
\hline Keywords: & Nigerian London, superdiversity, Ethnicity, urbanism, Space, visibility \\
\hline \multicolumn{2}{|c}{} \\
\hline
\end{tabular}

SCHOLARONE $^{\text {"x }}$

Manuscripts

URL: http://mc.manuscriptcentral.com/rers ethnic@surrey.ac.uk 


\title{
Nigerian London: remapping space and ethnicity in superdiverse cities
}

\author{
Caroline Knowles, Centre for Urban and Community Research, \\ Department of Sociology, Goldsmiths, University of London \\ c.knowles@gold.ac.uk
}

'The negotiation of space in the city is a continual dance of tolerance and intolerance, acceptance and violence, visibility and invisibility....' (Orsi, cited in Boutros 2010:120)

\section{Abstract}

This paper explores the idea of 'superdiversity' at the city level through two churches with different approaches to architectural visibility: the hypervisible Universal Church of the Kingdom of God and the invisible Igbo Catholic Church, both in North London, guide our exploration of invisible Nigerian London. Although Nigerians have lived in London for over two hundred years they live beneath the radar of policy and public recognition rather than as a vital and visible element of superdiversity. This paper argues that we can trace the journeys composing Nigerian London in the deep textures of the city thus making it visible, but this involves remapping space and ethnicity. It 
argues that visibility is vital in generating more open forms of urban encounter and, ultimately, citizenship.

Key words: visibility, urban space, ethnicity, superdiversity, Nigerian London.

\section{Introduction}

Superdiversity, the 'increased number of new small and scattered, multiple-origin, transnationally connected, socio-economically differentiated and legally stratified immigrants who have arrived over the last decade....' (Vertovec 2007:1024) is now an established descriptor of UK society generated by the 'new migrations' of the last fifteen-years. Conceptions of superdiversity combine, contest and fragment ethnicity and migration status, thus opening a space to develop more sophisticated notions of ethnicity in urban contexts as this paper suggest. Superdiversity extends dominant conceptions of multi-racial and multi-ethnic Britain beyond hypervisible South Asian and African Caribbean migrant-settler populations, and rightly offers this more complex picture as a critique of the nation-state's policy framework for the management of multi-racialism. But it does so without addressing visibility or the specifics of urban space. 
The (nation state) scale of the analysis of superdiversity sustains the problematic of 'integration' as a truncated politics of multi-racialism promoted in government policy and research agendas, and overlooks productions of superdiversity at more local-scales. However, it does disrupt settled ideas of ethnic territories in the city. Understanding places like Brixton in London as African Caribbean are subverted by new migrations, which are not apparent on the surface of place: Brixton is African as well as Caribbean. This paper argues that despite acknowledgement of superdiversity it hasn't yet been empirically explored or its spatial-theoretical implications fully developed. It suggests that we need to think about the micro-dynamics of superdiversity in the fabrics of the city where it is made, registered and lived. With one hundred and seventy nine nationalities and three hundred languages superdiversity is deeply imbricated in London, in co-productions of everyday lives and urban architectures. The paper argues that in order develop more sophisticated conceptions of superdiversity we need to better understand its everyday registration in the city. This involves adjusting our conceptions of the relationship between ethnicity and urban space so as to foreground both mobility and visibility. These theoretical adjustments open the way to conceptualizing and securing new forms of urban citizenship that are 
more openly engaged with the diversity of Otherness composing contemporary city life.

The problem with scaling superdiversity to the city-level is that it is not registered in ways that can be straightforwardly apprehended and mapped. Superdiverse ethnic-migrant presence has multi-registration points: in bodies, in clothing, in performances, in forms of commerce, in flows on money, in artifacts and buildings. These conduits of ethnic production and registration can be summarized as human and architectural fabrics, objects and social-technical processes. Some of these are more visible on city landscapes than others. But even hypervisible registrations conceal. Elaborate mosques' hypervisible announcement of religious presence in the city conceals equally important information in ethnic-migration-Islamic-orientation. Remittance flows have low visibility in the balance sheets of virtualtechnical space and high visibility in distant lifestyles, which are invisible from the city generating them. Visibilities are complicated and not just about what we see: seeing is anyway a skilled social practice (Jenks 1995:10) and in racially hierarchized societies, inevitably racialized. 
Visibilities involve complex dynamics of seeing and being seen, often embedded in the diffused power of surveillance (Tagg 1988): in who watches and who is watched? Mosques are not just architecturally hypervisible: they embed notions of dangerousness, which place them in the spotlight of (state-sponsored) urban surveillance. Hypervisibility equally generates the urban blind spots we can call invisibility, what is there but not seen, unimportant because it is not regarded as a threat or problem. In this sense African London is as invisible as Muslim London is hypervisible. Surveillance, of course, is only one layer of visibility: there are media visibilities which shape, but not determine, what we know and thus see; and there are visibilities of everyday urban engagement, as citizens navigate pathways through the city they visually take in a fraction of the landscape and interpret it with the tools available to them. These three prisms - surveillance, mediatized images and everyday visual navigation of urban landscape - provide the framework for thinking about visibilities. At opposite ends of the spectrum hypervisibility and invisibility both deny humanity and complexity (West 2001).

Visual traces of others' lives accumulated through daily city navigation are important in how urban citizens navigate and understand their cities and those with whom they share them. Recognition and 
resentment begin from the signs of otherness inscribed on the city's (human and built) surfaces. However, as my mosque example hints, and this paper will show, visual apprehension of ethnic co-presence is only a starting-point for deeper understanding of superdiverse cities. Apprehensions such as recognition, understanding, knowledge generation and theorization with which visual forms generate complex and sometimes contradictory dynamics are equally important. The relationship between ethnicized migrant presence in the city and the visual traces that carry that presence need to be teased out of the fabric of the city. As the cultural critic John Berger (2008) so wisely says, the relationship between what we see and what we know is never settled.

This paper explores fragments of everyday urban superdiversity through two empirical capsules, which presented themselves in the slip-stream of a research project on the salience of religion in the making of urban migrant lives 1 . The Universal Church of the Kingdom of God (UCKG), which has a high number of new Angolan migrants and the Igbo (Nigerian) Catholic Church, both in North London, ground fragments of new migration and London's superdiversity. In terms of ethnicity the 2001 census shows that the area around both churches has a similar profile: just over $70 \%$ white and between $13 \%$ and $14 \%$ 
black or black British. The Africans we are interested in are invisible in the way these figures were collected. Also congregations are not necessarily local. Presenting the Universal (Angolan/mixed) Church for contrasting styles of worship, subjectivity production and visibility on the urban landscape, this paper focus on fragments of Nigerian London glimpsed through the Igbo Church and suggests ways of exploring them. Contrast is not comparison, its is intended to unsettle, to imply constant emergent coproduction of ethnicity, subjectivity and urban landscape and so sustain 'Africans' and 'Nigerians' as contingent contextual open categories. And while this paper focuses on Nigerians I want to keep the mixed-black/Angolan congregation of UCKG in the frame for its contrasting approach to worship and architectural visibility.

\section{The Universal Church of the Kingdom of God}

The UCKG is a migrant Pentecostal Church. It has a large settled and new migrant congregation and has itself migrated from Brazil. Its congregation is $90 \%$ black comprising long and more recently migrated African Caribbeans and Africans including Angolans routed through Portugal. The 'church' - a term denoting the building and its congregants in collective worship - occupies what was once part of the 1930s chain of Astoria Cinemas, which later became a famous rock 
concert venue, the Rainbow Theatre, where Jimi Hendrix, Frank Zappa, Deep Purple and other 60s stars played. The building is hypervisible on the local urban landscape, its posters advertising its themed meetings - '13 ways to change your luck', four meetings a day seven days a week - visibly mark the business of god.

Its 'meetings' - the corporate term preferred to 'services' - are business and show business. Pastors in corporate casuals stand like security guards. The service begins when the Bishop leaps onto the stage and the piped music crescendos. The theme on one of my visits 2 was 'excuseitus', blaming others for adverse circumstances. Passages from Deuteronomy leavened the power-point presentation on personal responsibility: the Bishop's style suits the auditorium architecture. The congregants are mobile and vocal. The 'chain of prayer' is underwritten with standing orders into the UCKG bank account. Mid afternoon weekday services attract 100 plus, Sunday evenings $700-800$ and the Pentecost over 2000: the church is a force in local African migrant lives, and thus a significant node in African London.

\section{The Igbo Catholic Church}

Less than a kilometer away on the North side of Finsbury Park station the Igbo Catholic Church is as invisible as the UCKG is hypervisible. It 
lies on a recycled, once Irish, migrant route through the city. It's low visibility comes from being 'nested' inside a 'mainstream' Catholic Church, which is itself inside a plain neoclassical building originally intended to serve non-conformist religious worship - two layers of concealment which point to the difficulties of reading urban landscape for ethnicity and migrant presence. Its visibility comprises its web presence and the bodies that stand outside once a month at the beginning and end of services. Nested churches, an artifact of high London real estate values and declining congregations make efficient use of space designated for religious worship and share church expenses. Sunday mass attracting $50-80$ black and white congregants is followed by a second, 3 hour, service on the second Sunday of each month when the Igbo Catholic Church timesharing the building, brings 200-300 young Igbo congregants, a South Eastern Nigerian Diaspora people centred on Rivers State together constituting a shifting time-limited capsule of Nigerian London. The elderly Irish priest in the mainstream church acknowledges the vitality new migrants bring to his parish. He says: 'I bury the Irish and baptize the Congolese'.

In contrast to the mainstream Catholic service the Igbo celebration of mass is kinesthetic, informal and interactive. Congregants are mobile 
and vocal during the service, people drift in and out; children are passed around. Congregants and priests alike text and make phone calls during the service. Services are punctuated with drumming, dancing and singing. Women wear the brightly colored wrappers and elaborate head- scarves they may not wear every day in their work as teachers and nurses; men wear lounge suits or robes and trousers. Church Wardens circulate, greet and hover, distinguished by their green sashes. And the service is in the Igbo language. The Igbo priest says you are closer to God in your first language. He told me in one of our interviews:

No it's not purely about language. Theologically we preach the same Jesus. But I think the difference would be in terms of modality, how it's run, the attitude, you know we worship god by not standing or kneeling and praying. We add some flavor to it like clapping or dancing, so that's the difference. The people miss the history of it. That's why they come in here they want to clap their hands, they want to dance, they want to shout. So I think that's, if I will call it a theological difference, the message is all the same.

\footnotetext{
At Pentecost another layer, of pan-Africanism, surfaces: congregants from Zambia, Uganda, Togo and Congo mount rival choirs and dances and the service switches between Luganda, Lingala, Kadodo Ewe, Tilobe and Igbo. After service is socializing and networking in the
} 
church basement: beer, soft drinks and food are pulled from boxes and bags and the party begins.

\section{Built and Social Architectures}

And so in both of these churches through bodies, language, music, rhythm and dress new syncretic performances of migrant selves as London-based African Catholics and Pentecostals - significant productions of raced, time-layered, migrant ethnicities - are generated, making the mosaic of superdiverse London in ways that are unevenly visible in microcosms of urban landscape, in the fabrics of these recycled buildings. Production and registration of these microcosms of superdiversity is the announcement of migrant presence in the city: 'it is through their religious displays that urban people announced in their own voices the heterogeneity of cities' (Orsi 1999:48). The architectural announcement from UCKG is louder than from the Igbo Church: so here are two volumes at which Africans announce their presence in the city. Do these differences in volume and visibility matter? To whom might they matter? They matter because urban superdiversity is made in precisely these announcements. Whether it matters to African migrants and other urban citizens remains to be investigated. They might shape how non African Londoners think about their city. They might shape how African 
Londoners feel about the place through which their journeys are routed. For theorists of superdiversity, visibility pinpoints where the social architectures of superdiversity are generated, and so visibility matters for these reasons. It doesn't tell us all that we need to know but reveals places for further investigation.

Built architectures provide an entry-point to social architectures. Social architecture builds on Lefebvre's (2000) and de Certeau's (1988) ideas about space as textured by the social lives, social relationships and social processes it coproduces. Like buildings individual and collective lives have plans guiding their construction: activities, relationships, moral universes, and ways of being in the world. Exploring the social architectures of superdiversity in Angolan and Nigerian London involves drilling into the micro-fabrics of urban superdiversity. Of course these social architectures exist and compose fragments of urban fabric whether or not they are visible: in this narrower sense visibility is irrelevant. But in making these African social architectures known as part of the city, becoming part of knowledge about the city, visibility is important in alerting researchers and urban citizens that there is more to their city than at first appears. 
The UCKG adopts an interventionist approach to congregants' personal, work and family commitments in offering alternatives to migrant family life, accommodation (for some) inside the church, a social life and its own systems of church and personal advancement. It specializes in general human troubles with a migrant spin - finance, violence, relationships and aspiration - and hint at migrants' often precarious relationship with the city. UCKG's offer, and its congregant response, suggests the difficult dynamic new, multiply routed, African European migrants have with formal (state) and informal structures that mediate their presence in the city. Social architectures say as much about the city as its migrants.

Christina who is of mixed Angolan and Portuguese heritage and in her early twenties joined UCKG in Portugal as a child. The family's move to London when Christina was nine years old coincided with the 'arrival' of the HQ of UCKG in North London providing connections in the new city. Christina's relationship with the church developed at the age of 19 in a tangle of interpersonal difficulties and violence.

They have got services every day of the week and the church is open 24/7. And they have pastors who live inside the church and they all have their functions. They've got jobs that they do. Everybody has their tasks. ...I used to come for prayers on Mondays, pray for financial life. On Wednesdays I used to come for bible study and to grow more spiritually, to learn more about God. Thursdays I used to pray for my family. And on Fridays it was deliverance. Saturdays you come to evangelize and clean 
the church ... it was everything. It was my life. You don't have time for your family. You don't have time for your studies because you are always in church.... I just thought 'I am going to be a minister. I am going to go round the world and preach the word of god'... you bring all your money.

Christina sold what she had - her CDs and books - and donated the money to the church. In her early twenties at the time of this interview she had reduced her involvement thus lessening its impact on her life.

The migrant difficulties the Igbo Church addresses are those of an established and more prosperous congregation as well as young Nigerian Londoners and new migrants in need of help. Its priest describes himself as a 'missionary' by which he means:

... Conversion in all ramifications... It's not just come to my church. It's channeling your mind... helping to build the whole self. Be educated, do your works, get married, stay off crime, stay off drugs, be useful to yourself, be a good ambassador and then to help you achieve all these things; there is a model, there is Jesus. So that is actually the work of a missionary, being in prisons helping people, you know... I think that's the height of my missionary work; sitting with criminals, listening to them and helping them and trying to change them.

Conversations with the priest and a group of young women congregants (aged 13-15) suggest that the church provides a mechanism for living as Igbo-Nigerians-in-London: a guide for parents 
in how to live and rear children in values they recognize, respect and want to transmit - ways of living as migrants in their own language and reinvented traditions. Church is where the young girls meet and practice their Igbo. The priest suggests that Catholicism sustains London-Igboness:

Religion is not dying out. And I wonder if actually if religion will ever die out in the Igbo culture because religion is part and parcel of the life set up. It's buried in the language all the names are religious. You rarely get an Igbo name that is not routed to either god or goodness... So it's not dying out. Except that there are a few influences that tend to channel peoples attentions to other things. But eventually you see them come back. Once they pass that (teen) age, they come back once they are twenty-five, you see them gradually coming back. There are some numbers of them coming back either to marry in the Igbo church or because their parents put pressure on them. They see religion as a family thing...

This brief exploration of social architectures suggests London-based Igbo Nigerians in dialogue with other Africans, with their moral universe, (Taylor 1992) with the templates for being persons in the world, with normative frameworks guiding social relationships, social activities and ways of living. Existential and collective (racialized/ethnicized) selves are thus made in particular places in the city in relationship with specific gods and modalities of worship, albeit 
in invisible ways. Thus the church - as a building, as a set of consociations between congregants and as a set of moral and normative structures - literally produces (some) migrant lives in superdiverse London. And yet the time-place conjunctions of this church are invisible. How should we think about invisible place making and weak architectural registration of Igbo presence in the city? This question is best addressed through the other forms of visibility with which religious architectures coexists.

The rest of this paper centres on Nigerian London and addresses other layers of visibility: in official data, productions of knowledge and social policy. The arguments made about Nigerians in London apply equally to Angolans and other Africans too. They are equally invisible despite the architectural visibility of the UCKG, suggesting that architecture can only a starting point in uncovering the layers of visibility with which it is coproduced.

\section{Nigerian London}

As the Igbo Church alerted us, Nigerian London comprises multidimensional invisibilities. Nigeria was a British Protectorate from 1891 until independence in 1960: Nigerians deposited by the Trans Atlantic slave trade have lived in Britain for over 200 years. The main influx 3 
dates to the period after independence and reflects a demand for higher education among elite Nigerians who began arriving as students. Many delayed their return because of the Civil War (19671970) and lack of opportunities for professionals and entrepreneurs. Thus Nigeria lost to the UK (and the USA) its professional and entrepreneurial classes. 'New migrants' (Kyambi 2005) arriving from 1980 and captured in the 1994 Labour Force Survey and from 1990 and captured in the 2004 Labour Force Survey added further layers to longer-settled Nigerians in London. Data from the 2001 census and the Labour Force Surveys suggest that $78 \%$ of the 88,000 Nigerians who live in the UK live in London (Kyambi 2005) making it the UKs most Nigerian city. This figure discounts undocumented migrants and UK citizens of Nigerian descent (Hernadez-Cross et al 2006, cited Hein de Haas 2006), both factors that would raise this figure.

While we expect a fuller snapshot of Nigerian (and African) London as analysis of the 2011 census data unfolds there is little data currently available. We know from a recent DfID study (Hernandez-Cross et al 2006) of the UK-Nigeria remittance corridor that an estimated $\$ 5$ billion US in remittances in cash and electrical goods are repatriated to the South East and South West of Nigeria, confirming the Yoruba and Igbo character of Nigerian London. We also know that Nigerian London 
is geographically scattered through Hackney Central and Dalston, Lambeth, Newham, Southwark, Lewisham (Deptford) and Woolwich with outliers in Essex. We know that there are differences between layers of migrants. New migrants of the last fifteen years are a young population: $90.9 \%$ are below forty-five. New migrants have lower rates of employment than settled Nigerians: $61.2 \%$ are employed compared to $72.9 \%$ for settled migrants. They are more likely to be unemployed: $10 \%$ are unemployed compared to $5.1 \%$ for settled Nigerians. There are more new Nigerian migrants (15.3\%) in education than settled migrants (5.2\%) and only $37.4 \%$ of them have higher qualifications compared to settled-Nigerians (50.7\%). As far as low-earners (below half the median wage) are concerned new Nigerian migrants $(18.5 \%)$ fare worse than settled migrants (14.2\%) but better than the UK average (21\%) (Kyambi 2005:86), suggesting their socioeconomic profile may incline them towards better employment opportunities. Despite time-layered differences Nigerian London is educated, employed and earning better than the UK median wage.

\author{
Nigerian London is invisible in popular and official estimates of social \\ problems. Being 'problematic' of course constructs visibility through \\ disapproval. Unlike Bengalis, Nigerians are not accused of integration \\ failure; unlike African Caribbean and South Asians they are not
}


associated with poverty or inner city riots; and unlike Muslims from other parts of Africa, South Asia and the Middle East, Nigerians are not associated with terrorism, despite Umar Farouk Abdul Mutallab -a Nigerian student - who boarded a flight from London to Detroit in 2009 with explosives strapped to his legs. Nigerian London lies below the radar of public notoriety, official data and social policy. Consequently Nigerian needs do not demand address. These invisibilities corroborate the Igbo Catholic Church's strategy and coexist with the hypervisibility of Muslims.

Nigerian London is also invisible in analyses of race and ethnicity in Britain (Harris 2006:2), which focuses on numerically more significant South Asians and Caribbeans. Harris' authoritative study of the Southern Nigerian Yoruba in London, Carey's (1956) Colonial Students, Craven's (1968) West Africans in London and Killingray's (1994) chapter on Africans in the United Kingdom sum up the research output. And, as these titles suggest, they rarely warrant separate attention from other Africans who anyway feature more prominently in the literature on 'development' (Zack-Williams and Uduku eds. 2004). An electronic search through in the Journal Ethnicity and Migration (JEMS) produced a few articles on Ghanaians related to work, community and therapy. A search of Ethnic and Racial Studies brought 
only two results: Charles Ukeje and Wale Adebanwi's (2007) analysis of Yoruba and Ijaw nationalism in Nigeria and Steven Vertovec's excellent paper on superdiversity.

Pentecostalism (Harris 2006:4) opened a narrow investigative window onto Nigerian London. Harris' (2006:5) study of the Cherubim and Seraphim Church, reveals that Yoruba church members saw themselves as a nascent national elite, 'agents not victims of disadvantage' thus disturbing the dominant interpretation of black migrants in Britain as poor, deserving sympathy or hostility. In this study we glimpse the elite of a post independence state equipping themselves with the educational tools for self-governance, implicitly cast as the disadvantaged victims of the postcolonial state from which they had so recently liberated themselves and as exotic members of alternative religious congregations. Jane Ifekwunigwe's (1999) lyrical poem on mixed British-Nigerian identities draws Nigerian migrant presence along the narrow trajectory of identity and belonging. In sum, scholars of race and ethnicity have contributed to the invisibility of Nigerian London.

In summing up so far I note the following. Probing a 'hidden' church exposes a rich site of migrant life. These social architectures are 
obscured by - official, popular and academic - neglect of Nigerian

migration so that Nigerian London lies buried in the surface of the city. The invisibility of the church and Nigerian London are co-produced and Nigerian London does not become a constituent of the city's superdiversity. Instead official, popular and academic attention more fiercely scrutinizes other groups of (new and settled) migrants sustaining their hypervisibility: a distorted record of the city emerges. Can Nigerian London become visible without also becoming a problem or an object of resentment? Is religion an appropriate window onto Nigerian London?

\section{God's City: Religion as a Window onto Nigerian London}

The two churches suggest religion is a rich source of migrant life making. I suggested that religion exposes fundamental aspects of urban social fabric in the production of (ethnicised) subjectivities and their moral universes in addition to social practices and everyday lives that extend beyond formal religious worship. And, as I shall show later, religion reveals important aspects of migrants' relationship with the city: it draws some of the cartographies of Nigerian London.

Religion has become an important source of knowledge about the production of urban ethnicity (Peach 2006, Modood et al 1997). For 
example intersections between religion and ethnicity reveal South Asian 'encapsulation' and 'social closure' producing distinct patterns of ethnic residential segregation in East London (Peach 2006). Modood et al (1997) show that religion is vital in framing British South Asian identities sustaining theoretical elaboration of urban ethnicity. But this literature indicates an important point about religion: Islam is prioritized (with some attention to Pentecostalism). Widely assumed as problematic, Islam has become hypervisible: Christianity, assumed as unproblematic, normative and white is rarely a way of exploring urban ethnicities.

Religion has elaborated our understanding of migration rather than ethnicity (Harris 2006, Hagan and Ebaugh 2003:1145, Kraus 2011, Hunt and Lightly 2001) and this is obviously central in understanding superdiversity. Pentecostalism, for example, is shown to be a resource in undocumented migration (Hagan and Ebaugh 2003:1145): facilitating planning, travel, and ready-made support-structures in new settlement. Religion reveals the migrations of 'reverse mission' in which Europe becomes the Dark Continent in a re-appropriation of missionary practices that once flowed in the opposite direction, thus, itself becoming a motive for migration. Religions are acknowledged sites for translocal living and local and translocal civic engagement 
(Levitt 2001, 2003, 2007, Koser 2003); all issues that have a bearing on the elaboration of superdiversity. Transnational social fields are generated through religions: Catholicism is a globally calibrated social system connected by traveling clergy (Byre 2001, Casanova 1994 cited Levitt 2003) and a resource in transnational living. Religion operates in dynamic webs of shared meanings across different social contexts (Levitt 2003). These approaches are, however, centred on translocality and new syncretic ethnic identities, a narrower understanding of ethnicities, not extended to their registration in local everyday life and superdiverse productions of city space.

Islamic religion is understood as a window onto migrants' city making in architectural form (which side steps ethnicity). A number of authors (Gale 2005, de Galembert 2005, Jonker 2005, Manco and Kanmaz 2005, McLoughlin 2005 and Biondo 2006) provide analyses of European urban population's relationship with Islam through mosque construction in Italy, the UK, Belgium, Holland, Germany and France. Ignoring other religions this secures Islam's hypervisibility. It rightly notes that mosques register the presence of migrants of Islamic faiths in the public spaces of the city: 'The mosque not only expresses the presence of a local Muslim community, it also represents the evolution of Islam from the private to the public sphere' (Cesari 2005:1018). 
Visibility (along with ethnicity) is not discussed but implied in the notion of 'public', although, as I argued earlier, being public doesn't itself confer visibility. In our study of religion we found 'public' mosques in Hamburg concealed in car parks, and at the back of discos: all muted announcements of Muslim presence in the city.

This literature focuses on struggles between European Muslims and planning authorities, which are read as symbolic of the (marginal) terms on which Muslims can pursue European settlement. Thus the visual is read as symbolic of a set of political conditions, standing for something beyond, for geographies of resentment and understandings of ethnicity that are not elaborated. Overarching geographies of resentment and exclusion may obscure important if small dynamics of inclusion and local connection as well as overestimate the significance of religion in migrants' everyday lives. This adds grist to the view that migrants' live parallel lives, which are important matters for investigation, not simply read from urban architecture. The relationship between religious faiths, the architectures of its public registration, the often-invisible social architectures with which built architectures weakly correspond and the social salience of all of this in apprehending and understanding superdiversity are not as easily settled as these mosque debates suggest. 
The significance of religion in understanding urban superdiversity is inescapable: even Christianity, which is anything but normative and white, is significant. According to the $4^{\text {th }}$ English Church Survey (2005) $44 \%$ of London church congregations - a mixture of new and settled migrants and locals - are black at a time when the privatization of faith and personal gods are replacing collective worship in so-called 'secular cities' 4 . The traveling faith of new migrants is widely acknowledged to bring new life and energy. Religious faith and its re-cycled architectural manifestations are a crucial part of the fabric of cities (Orsi 1999:43-4,54): places where the city is generated and reworked. Religion marks adjacent social worlds (Orsi 1999) as the Igbo Catholic church shows. Churches display the tactics migrants adopt in superdiverse cities; they register the 'balance between revelation and self effacement, display and concealment' (Orsi 1999:49). And this makes them rich sites for enquiry into new migrations, ethnicity and urban superdiversity.

\section{Spatialising Superdiversity}

\section{Urban Landscape}

Noting the limitations of superdiversity earlier as not imbricated in urban space, it is important to rethink our understanding of the 
relationship between ethnicity and urban landscape as a step towards the multi-forms of migrant-ethnic-registration that constitutes superdiversity. Departure points are provided by Amin and Thrift (2002) and Swanton (2010) who have explored some of the ways in which ethnicity is imbricated in everyday urban encounter. Taxi proximities (Amin and Thrift 2002) and 'road rage' (Swanton 2010) capture cities as 'sites for intensive ethnic mixing' as 'local microcultures of inclusion and exclusion' (Amin and Thrift 2002:291) in the 'racisms of assemblages' and their 'fuzzy racial summaries.... rapid practices of perception and judgment' (Amin and Thrift 2002:460). Bodily interactions in moments of everyday casual encounter take race and ethnicity into the fabric of the city itself making it part of the urban visual economy (Swanton 2010:450).

While these analyses work better in accounting for human-interactive than built city fabrics, they offer insights on the discrepant performances architectures sustain, like those that erupt around churches at the beginnings and ends of services as moments of public interface. Their limitation lies in in their treatment of fleeting encounter as urban-spatial-racial-experience disconnected from other moments and places in which race and ethnicity are salient in citymaking in more prolonged ways. Their urban racial incidents are 
coproduced within a wider connected/disconnected city grammar of race/ethnicity in dialogue with other surfaces of encounter and architecture.

Amin and Thrift's analysis however opens a space for further questions and a better, emergent and provisional, mapping of the relationship between race/ethnicity and urban space than other approaches. It provokes questions such as what contextualizes the encounters they discuss? What other registrations of race/ethnicity are coproduced? Are there connections between them and what are they? What other iterations of ethnicity imprint the same urban surface and ambiguous architectural manifestations and how should we think about them? Their analysis needs to be extended to urban connective tissue and space: while it is mobile it is not joined-up.

\footnotetext{
Questions such as these inaugurate deeper and broader analysis of urban landscape and architectural manifestations and performances. As the Igbo Catholic Church shows, urban landscape is an unreliable guide to urban social morphologies. Urban landscape is always duplicitous. The issue is how to penetrate its duplicity? How to better see what doesn't necessarily present itself to the eye but is never the less still there?
} 
This is neither a matter of reading the surface better nor uncovering truth beneath the surface as Marxist cultural geographers suggest (Berger 2008). Landscape is better understood as a shared, lived-in world (Merleau-Ponty 1969:256): not the surface on which dwelling takes place, but dwelling itself. Ingold's (2000) notion of surface as deeply textured by human activity and objects of material culture (including architecture) is useful. With it I want to suggest that the urban surface is a deep surface for excavation and discovery: it can reveal invisible lives in the city and points to the importance of research into the little 'discovered' urban citizens comprising superdiversity.

Excavating this urban surface for its invisible substance, its human and concrete fabric and fabrications is the challenge we face. Nigerian Catholics along with other city dwellers make their city, but they do so subtly, alert to others, in ways that demand exploration. How do Nigerians 'do' migration in this city along these crucial (religious) borders between urban social worlds? New research agendas addressing these questions will make Nigerian superdiverse London visible, just as new ways of mappin intersections between ethnicity 
and urban space also reveal them as I show in the section following where migrant lives are mapped onto city space as journeys.

\section{Journeys - mapping Nigerian London}

Migrants' local and translocal travel practices (journeys) reveal both their cities and themselves (Knowles and Harper 2009, Knowles 2011). Journeys involve forms of improvisation and planning, way finding and the navigation skills - practical knowledge of the world - required to navigate deep urban surfaces (Ingold 2000). Journeys around and between cities offer the possibility of exploring the co-scripting of landscape, movement and biography in urban migrants. Churches are not privileged city audit points, but I have shown that they reveal fragments of Nigerian London, and are thus a viable point of entry into journeys passing through them. The pages following suggest what these journeys might be, demonstrate the effectiveness of migrants' journeys as an analytical tool for excavating superdiversity in the city, and raise questions for further research.

Journeys routed through the Igbo Catholic Church are drawn by the matrix of routes connecting the church to other places and by the movements of congregants themselves. The Church is connected to UK Catholicism through the diocese of Westminster and through this to 
the Papal authority in Rome and its global networks. This exists in parallel to a second set of connections to Rome through the Nigerian Catholic church. The Igbo catholic priests are missionaries operating from their diocese in Warri, in SE Nigeria, as well as being part of the diocese of Westminster. Igbo congregations and ministers thus operate two routes. Firstly to the (UK) parishes in which they worship and to the diocese to which those parishes belong, and secondly to the Igbo congregation nested in North London and connected by its missionary priests to the diocese of Warri. These church-drawn routes coexist with municipal ones. Parishes span the boroughs of Hackney and Islington, which organize garbage collection, education and so on.

Congregations generate a series of routes on top of those drawn by church and municipal geographies, routes navigated between the church and where they live, or have lived. These incorporate new allegiances with the (traveling) Igbo Church, partly anchored in Warri, and time-sharing with other Catholic congregations in Finsbury Park. Congregants' journeys traverse NE London and Essex: few still live in Finsbury Park. Church and related cultural activities - like Igbo literature and dancing promoted at Sunday services - involve the extension of routine journeys such as visits with friends, family, work and leisure. Church services also consolidate professional, friendship 
and family networks, which are important in this aspirational, congregation of teachers, nurses, lawyers and doctors.

Igbo Nigerians also navigate personal translocal journeys between London and South Eastern Nigeria for family visits. At Christmas congregants return to Nigeria to be with non-migrant relatives or meet those routed to the US.

This matrix of migrant journeys along with those we haven't traced, and those that are not routed through this church, make Nigerian London. While this is largely invisible, fragments are registered on the urban landscape in various places if we treat the surface as a place for careful investigation of migrant-ethnicities. These journeys overlay those of Irish migrants who have long since moved to other parts of London leaving traces of their journeys in pubs and churches. The routes of one set of migrants provide the ground across which more recent arrivals travel too, as is often the case in UK cities.

\section{Conclusion: Visual Registration of Multi-Ethnic Presence}

This paper has shown that everyday city-level analysis of superdiversity requires a remapping of space and ethnicity, tracing migrant-city making through deeply textured urban surfaces as journeys. Journeys connect local and translocal space thus working at 
different scales, connecting small fragments of Nigerian London, Angolan London and so on, thus adding to the complex maps that reveal the superdiverse city, otherwise invisible in social policy and race scholarship.

\begin{abstract}
Approaching connections between migrant-ethnicities and urban space through journeys acknowledges the contextual, contingent, ad hoc, improvised nature of both urban ethnicities and space. It is a form of conceptualization that maps easily onto methods of empirical investigation, thus avoiding the abstraction of superdiversity from its social contexts. It also allows the mapping of specificities that avoids essentialising and generalizing either ethnicities or space so challenging the ossification of urban space in formulations such as 'China town' and 'Little Italy' keeping space open, fluid and emergent. It does the same for ethnicity. While I claim in this paper to be tracing some of the contours of Nigerian London, mapping journeys allows for discrepant and infinitely varied versions of London-Nigerian-ness. The journeys I trace are Igbo, Catholic, professional and pass through NE London in 2011. Migrant journeys are ethnicised, classed time-spacebiographical productions that potentially unpack the aggregation of lives that 'Nigerians' or even 'London-Nigerians' involves. Thus the journey provides a sensitive investigative tool with which to map the
\end{abstract}


less visible constituents of superdiversity. I have also suggested that Christian religions are a rich audit point from which to map these journeys because they reveal the social architectures of urban migrant lives and subjectivities.

Tracing journeys requires some visible registration points. The city both conceals and displays superdiversity. The two African churches in this paper show this. They are hypervisible and invisible gatheringpoints along two shifting networked routes through the city made by the invisible African migrants that navigate them. Journeys passing through the Igbo Church leave traces in the deep textures of the urban surface producing the human fabric, social architectures and routes composing Nigerian London and superdiversity whether or not they are visible. Urban landscapes provide a shifting archive of human action, time layered journeys and modes of being that both obscure and articulate lived experience (Daniels, cited Tilly 1994:25). In this respect visual manifestations of urban superdiversity are irrelevant. The visual traces of others' lives, social systems, preoccupations and journeys are all around us, whether or not we acknowledge them. Does visibility, coproduced in urban landscape, in public policy, in academic research and in official data actually matter? 
There are at least two reasons why it does. Firstly low visibility superdiversity reflects badly on cities. Strategies of display and concealment express a relationship with the city as a migrantreceiving context in addition to preferred modes of migrant selfpresentation. Invisibility reflects city migration politics marking it as inhospitable in the navigation of immigration rules and procedures, in securing jobs and housing, in hostility and violence on the streets and negative media treatment.

Secondly, active co-presence between urban citizens involves registering traces of the other. As Michael Keith elegantly expresses it, we need both a 'vocabulary and a lens through which the spatial is made available' (Keith 2005:62). Urban spaces in which superdiversity can be visibly articulated sustain active co-presence of urban citizens in proximate worlds. Tracing the routes composing Nigerian London, making them more visible, understanding Nigerian migrants' routes through the city and their connections with other places; Knowing how Nigerians 'do' migration in the city along these crucial borders between social worlds provides such a lens. The feedback loop between visual apprehension and knowledge of other's routes through the city make us fellow travellers. It provides the basis for acknowledgement, recognition and respect, capacities for navigating 
co-presence that would greatly improve life in superdiverse cities in providing the impetus for, and curiosity about, the other and an impulse to make connection, however slight. Feeling empowered to mark a visible presence in the superdiverse city is an important step towards active civic engagement and rights to the city however difficult this journey through the territories of resentment might be.

\section{Notes}

1. The research project from which the material for this paper was derived was funded under the NORFACE Religions Programme and was a three-city (London, Hamburg and Oslo) investigation of religion as a social force among young people in these three cities, titled 'The Architectures of Contemporary Religious Transmission'. The data presented in this paper is a by-product of that research and not its central focus. This is intended as a theoretical not empirical paper.

2. The Universal Church of the Kingdom of God denied us research access. The data we have comes from attending their public 'meetings' and interviewing a group of young people who had left or greatly reduced their commitments to the church.

3. Nigeria is part of a swirl of in and out migration. Its estimated 140 million population, 90 million of which live on less than $\$ 1$ a 
day is a source of new migrants across Europe, the Gulf and Southern Africa (Hein de Haas 2006). And Nigeria is a key destination among West African migrants making it both a sending and a receiving country.

\section{References}

AMIN, ASH \& THRIFT, NIGEL (2002) Guest Editorial, Special Issue: Cities and Ethnicities, Ethnicities, Vol.2 No.2 pp291-300

Berger, J (2008) Ways of Seeing, London: Penguin BIONDO, VINCENT F (2006) 'The Architecture of Mosques in the US and Britain, Journal of Muslim Minority Affairs, Vol.26 No.3 pp399-420 BOUTROS, ALEXANDRA (2010) The Spirit of Traffic: Navigating Faith in the City' in Alexandra Boutros and Will Straw eds. Circulation and the City, Montreal: McGill-Queens University Press, p118-137

CAREY, ALEXANDER, TIMOTHY (1956) Colonial Students: A Study of the Adaptation of Colonial Students in London, London: Warburg

CESARI, JOCELYNE (2005) 'Mosques in French Cities: Towards the End of a Conflict' Journal of Ethnic and Migration Studies, Vol.31 No.6 pp1025-1043 
COSGROVE, DENIS \& DANIELS, STEPHEN (1988) The Iconography of Landscape, Cambridge: Cambridge University Press

CRAVEN, ANNA (1986) West Africans in London, London: Institute of Race Relations

DE CERTEAU, MICHEL. (1988) The Practice of Everyday Life, University of California Press

DE GALEMBERT, CLAIRE (2005) 'The City's 'Nod of Approval' for the Mantes-la-Jolie Mosque Project: Mistaken Traces of Recognition' Journal of Ethnic and Migration Studies, Vol.31 No.6 pp1141-1159 DE HASS, HEIN (2006) International Migration and National Development: Viewpoints and Policy Initiatives in Countries of Origin: The Case of Nigeria, Report Prepared for the International Migration Institute, James Martin $21^{\text {st }}$ Century School, University of Oxford. www.imi.ox.ac.uk/pdfs/nigeria-migration-and-development-hein-dehaas.pdf

GALE, RICHARD (2005) 'Representing the City: Mosques and the Planning Process in Birmingham' Journal of Ethnic and Migration Studies, Vol.31 No.6, pp1161-1179

GALE, RICHARD \& NAYLOR, SIMON (2002) 'Religion, Planning and the City' Special Issue: Cities and Ethnicities, Ethnicities, Vol.2 No.2, pp387-409 
HAGAN, JACQUELINE \& EBAUGH, HELEN ROSE (2003) 'Calling Upon the Sacred: Migrants' Use of Religion in the Migration Process' International Migration Review Vol.37, No.4 pp1145-1162

HARRIS, HERMIONE (2006) Yoruba in the Diaspora: An African Church in London, Basingstoke: Palgrave

HUNT, STEPHEN \& LIGHTLY, NICOLA (2001) 'The British Black Pentecostal Revival: Identity and Belief in the New Nigerian Churches' ERS Vol.24, No. 1 pp104-124

IFEKWUNIGWE, JANE O. (1999) Scattered Belongings, London: Routledge

INGOLD, TIM. (2000) The Perception of the Environment: Essays in livelihood, dwelling and skill, London: Routledge JENKS, CHRIS (1995) 'The Centrality of the Eye in Western Culture: An Introduction' in Jenks, C (ed) Visual Culture, London: Routledge JONKER, GERDIEN (2005) 'The Mevlana Mosque in Berlin-Kreuzberg: An Unresolved Conflict', Journal of Ethnic and Migration Studies, Vol.31 No.6 pp1067-1081

KEITH, MICHAEL (2005) After the Cosmopolitan, London: Routledge KILLINGRAY, DAVID (1994) 'Africans in the United Kingdom: An Introduction' in David Killingray ed, Africans in Britain, Ilford: Frank Cass KNOWLES, CAROLINE (2011) 'Cities on the Move: Navigating Urban Life' CITY Vol.15, No.2 pp136 -53 
KNOWLES, CAROLINE \& HARPER, DOUGLASS (2009) Hong Kong: Migrant Lives, Landscapes and Journeys, Chicago: University of Chicago Press

KNOWLES, CAROLINE (2008) The Landscape of Post-Imperial Whiteness in Rural Britain' Special Issue of Ethnic and Racial Studies on Whiteness Vol.31 No.1

KNOWLES, CAROLINE (2003) Race and Social Analysis London: Sage KOSER, KALID (2003) ed. New African Diasporas: An Introduction, London: Routledge

KRAUSE, KRISTINE (2011) Cosmopolitan Charismatics? Transnational ways of Belonging and Cosmopolitan Movements in the Religious Practice of New Mission Churches, ERS Vol.34, No.3 pp419-435

KRAUSE, KRISTINE (2009) Spiritual Spaces in Post-Industrial Places: Transnational Churches in North East London' Michael P Smith and KYAMBI, SARAH (2005) Beyond Black and White: Mapping New Immigrant Communities, London: IPPR

LEFEBVRE, HENRI (2000) Writing on Cities London: Blackwell

LEVITT, PEGGY (2001) 'Transnational Migration: taking stock and future directions' Global Networks, 1,3 pp195-216 
LEVITT, PEGGY (2003) 'You Know Abraham was Really the First Immigrant: Religion and Transnational Migration', International Migration Review, Vol. 37 No.3 pp847-873

LEVITT, PEGGY (2007) God Needs No Passport, New York: The New Press

MANCO, URAL \& KANMAZ, MERYEM (2005) 'From Conflict to Cooperation Between Muslims and Local Authorities in a Brussels Borough: Schaerbeek' Journal of Ethnic and Migration Studies, Vol.31 No.6, pp1105-1123

MCLOUGHLIN, SEAN (2005) 'Mosques and the Public Space: Conflict and Co-operation in Bradford' Journal of Ethnic and Migration Studies, Vol.31 No.6, pp1045-1066

MODOOD, TARIQ (1997) 'Religion' in Tariq Modood, Richard Berthoud, Jane Lakely, James Nazroo, Patten Smith, Satnam Virdee and Sharon Beishon (eds) Ethnic Minorities in Britain: Diversity and Disadvantage, London: Policy Studies Institute

MERLEAU-PONTY (1969) Phenomenology of Perception, London Routledge

Orsi, R. A. 'Introduction: Crossing the City Line' In Orsi (ed) (1999) Gods of the City p51 pp1-78 Bloomington: Indiana University Press 
PEACH, CERI (2006) 'Islam, Ethnicity and South Asian Religions in the 2001 Census', Transactions of the Institute of British Geographers, pp353-370

STYAN, DAVID (2003) 'La Nouvelle Vague? Recent Francophone African Settlement in London' in Kalid Koser ed. New African Diasporas, London: Routledge

SWANTON, DAN (2010) 'Flesh, Metal, Road: tracing the machinic geographies of race', Environment and Planning D: Space and Society, Vol.28 (3) pp447-466

TAGG, JOHN (1988) The Burden of Representation: Essays on Photographies and Histories, Amherst: University of Massachusetts Press

TAYLOR, CHARLES (1992) Sources of the Self, Harvard University Presss

UKEJE, CHARLES \& ADEBANWI, WALE (2007) 'The Ethno-nationalist Claims in Southern Nigeria: Insights from Yoruba and Ijaw Nationalism Since the 1990s, ERS, Vol. 31, No.3 pp563-591

LEFEBVRE, HENRI (2000) Writing on Cities London: Blackwell The $4^{\text {th }}$ English Church Survey (2005) www.christianresearch.org VERTOVEC, STEPHEN (2007) 'Superdiversity and its Implications' ERS Vol. 30 No. 6 pp1024-1054 WEST, CORNEL (2001) Race Matters, New York: Vintage 
WYLIE, JOHN (2007) Landscape, London: Routledge 